\title{
The valuable effects of potent antioxidant curcumin in cisplatin induced liver and kidney injury
}

\section{Güçlü antikosidan kurkuminin sisplatinin neden olduğu karaciğer ve böbrek hasarında önemli etkileri}

Nursah Basol ${ }^{1}$, Aslı Yasemen Savas², Ayfer Meral ${ }^{3}$, Oytun Erbas ${ }^{4}$

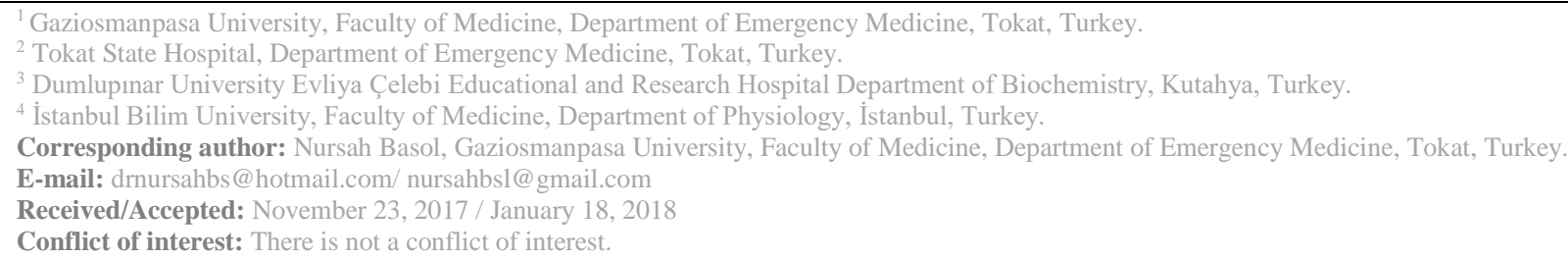

\section{SUMMARY}

Objective: Cisplatin (CIS) is a potent anticancer drug that uses commonly. The toxic effects of CIS limit its usage. In the present experimental study, it is aimed to evaluate effects of curcumin (CUR) on CIS induced hepatotoxicity and nephrotoxicity.

Method: The rats were separated into three groups as each composed of 7 rats. First one is control group, the second is the CIS (6 mg/kg, i.p) + saline group, and third is the CIS (6 mg/kg, i.p) + CUR (100 mg/kg i.p) group. CIS was given at single dose and CUR was given for 3 days. After 3 days, kidney, liver and blood samples were analyzed with histopathological and biochemical technics.

Results: In CIS+ CUR group, there was decline in levels of Blood urea nitrogen (BUN), alanine aminotransferase (ALT) ALT and compared with CIS group. Besides, superoxide dismutase (SOD) and glutathione (GSH) levels were found increased as compared with CIS group. The ameliorating effects of CUR were presented with histopathological findings.

Conclusions: CIS has serious toxicity on kidney and liver and oxidative stress play an important role on toxicity. The present study suggests that CUR has important healing effects on nephrotoxicity and hepatotoxicity of CIS.

Keywords: Cisplatin, curcumin, nephrotoxicity, hepatotoxicity

\section{ÖZET}

Amaç: Sisplatin (CIS) sıklıkla kullanılan oldukça güçlü bir anti kanser ajandır. Sisplatinin toksik etkileri kullanımını sinırlandırmaktadır. Sunulan bu deneysel çalışmada, sisplatinin nefrotoksik ve hepatotoksik yan etkilerine karșı kurkuminin (CUR) etkilerinin incelenmesi amaçlanmıştır.

Yöntem: Sıçanlar her biri 7'şerli toplam 3 gruba ayrıldı. İlk grup, control grubu olarak, ikinci grup CIS (6 mg/kg, i.p)+ salin grubu ve 3. grup CIS (6 mg/kg, i.p) + CUR (100 mg/kg i.p) olarak belirlendi. Sisplatin tek doz olarak ve kurkumin ise 3 gün boyunca sıçanlara verildi. 3 gün sonra, karaciğer ve böbrek dokuları ve kan örnekleri histopatolojik ve biyokimyasal tekniklerle analiz edildi.

Bulgular: Sisplatin+ kurkumin gurubunda BUN ve ALT değerleri sadece sisplatin uygulanan gruba göre daha düşük bulundu. Bunun yanında, SOD ve GSH düzeyleri sadece sisplatin verilen grupta CIS+CUR grubuna göre daha yüksekti. Karaciğer ve böbrek dokusunda histopatolojik olarak kurkuminin yararlı etkileri gözlendi.

Sonuç: Sisplatin böbrek ve karaciğer dokuları üzerinde güçlü bir toksik etkiye sahiptir. Sunulan bu çalışma; kurkuminin, nefrotoksik ve hepatotoksik yan etkileri iyileştirmede önemli bir etkisi olduğunu öne sürmektedir.

Anahtar sözcükler: Sisplatin, kurkumin, nefrotoksisite, hepatotoksisite 


\section{INTRODUCTION}

Cisplatin (CIS), a non-cycle-dependent cytotoxic platinum, is one of the most effective and commonly used anticancer agent ${ }^{1,2}$. It is used for the treatment of various human solid tumors as lung, bladder, stomach, ovarian, head and neck cancers $^{3,4}$. The initial plasma elimination half-life of CIS is 25-50 minute but the half-life of bound and unbound CIS is more than 24 hours after intravenous injection. It is bound to plasma proteins and it can be found in kidney, liver, intense and testes tissues in large quantities ${ }^{5}$. Although the high doses of CIS are more efficient to cancer treatment, the dose dependent toxic effects of CIS create problems in usage ${ }^{6}$. CIS shows first toxic effects on kidneys ${ }^{5}$. Besides nephrotoxicity, it has hepatotoxic, neurotoxic and ototoxic potency ${ }^{7}$. Although the main mechanism is not clear, some mechanisms hold responsible from the pathogenesis of CIS toxicity. To our knowledge, in literature, there are some reports that investigate toxic effects of CIS and especially its nephrotoxicity. Accordingly, it is thought that primarily responsible mechanism is oxidative stress due to abnormal production of reactive oxygen molecules ${ }^{6}$. Therefore, recent experimental studies focused on potential impacts of antioxidants in pretreatment or treatment stages of CIS induced toxicity. Besides other beneficial effects, the antioxidants play an important role on protection of tissues against deleterious effects of reactive oxygen species and other free radicals ${ }^{8}$.

Curcumin (CUR), major component of turmeric, is extracted from the rhizome of Curcuma Longa 9. Turmeric is used as a spice and also has been used in medication for thousands of years in Asia ${ }^{10}$. CUR is responsible from beneficial effects of turmeric. The antioxidant, anti-inflammatory, anticarcinogenic, antimicrobial and antimutagenic effects of CUR have shown by recent studies ${ }^{11}$. It is reported that CUR prevents lipid peroxidation, reacts with reactive species and induces an upregulation of various cytoprotective and antioxidant proteins ${ }^{12}$. Hereby, CUR shows bifunctional antioxidant effects. The increasing oxidative stress is due to CIS nephrotoxicity and hepatotoxicity, thus CUR that is a potent antioxidant can show beneficial effects on toxicity of CIS.

To the best of our knowledge, there is no study that evaluates effects of curcumin on both cisplatin related kidney and liver injury in same animal models. With the present study, it is aimed to investigate potential beneficial effects of CUR against to deleterious impacts of CIS on kidney and liver tissues.

\section{MATERIAL AND METHODS}

\section{Animals}

In this study 21 male Sprague Dawley albino mature rats weighing 200 to $220 \mathrm{~g}$, were used. Animals were fed ad libitum and housed in pairs in steel cages having a temperature-controlled environment $\left(22 \pm 2{ }^{\circ} \mathrm{C}\right)$ with 12-h light/dark cycles. The experimental protocol was approved by the Committee for Animal Research of Gaziosmanpasa University. All animal studies are strictly conformed to the animal experiment guidelines.

\section{Drugs}

All drugs were freshly prepared. Curcumin (Sigma, Aldrich) was dissolved in high volume saline $(0.9 \% \mathrm{NaCl})$ that was used as control solution. All solutions were administered intraperitoneally (i.p.).

\section{Experimental design}

21 male Sprague Dawley albino mature rats were used in the present study. Rats were randomly assigned into 3 groups. Group $1(n=7)$ was control group and was administrated no drug. 14 rats were given single dose $6 \mathrm{mg} / \mathrm{kg} /$ day cisplatin (Cisplatin, Kocak, $50 \mathrm{mg} / 100 \mathrm{~mL}$ ). These rats divided randomly two groups [n=7]. First group rats [Group 2] was given $1 \mathrm{ml} / \mathrm{kg} /$ day $\% 0,9 \mathrm{NaCl}$ saline for three days. Second group rats (Group 3) was given $100 \mathrm{mg} / \mathrm{kg} / \mathrm{day}$ curcumin i.p for three days. Then, the animals were euthanized and blood samples were collected by cardiac puncture for biochemical analysis and bilateral hepatectomy and nephrectomy were performed for histopathological and biochemical examinations.

\section{Determination of BUN levels}

Blood urea nitrogen (BUN) concentrations were determined spectrophotometrically using an automated analyze system. BUN and creatinine concentrations were expressed $\mathrm{mg} / \mathrm{dl}$.

\section{Determination of plasma ALT levels}

Plasma ALT levels were measured using commercially available (ELISA) kit (USCN, Life Science Inc.).

\section{Determination of lipid peroxidation}

Lipid peroxidation was determined in tissue samples by measuring malondialdehyde (MDA) levels as thiobarbituric acid reactive substances 
(TBARS) ${ }^{13}$. Briefly, trichloroacetic acid and TBARS reagent were added to the tissue samples, then mixed and incubated at $100{ }^{\circ} \mathrm{C}$ for $60 \mathrm{~min}$. After cooling on ice, the samples were centrifuged at $3000 \mathrm{rpm}$ for $20 \mathrm{~min}$ and the absorbance of the supernatant was read at $535 \mathrm{~nm}$. MDA levels were calculated from the standard calibration curve using tetraethoxypropane and expressed as $\mathrm{nmol} / \mathrm{gr}$ protein.

\section{Determination of tissue superoxide dismutase (SOD) Activity}

Total SOD activity was determined according to the method of Sun et al. ${ }^{14}$. The principle of the method is the inhibition of nitrobluetetrazolium (NBT) reduction by the xanthine-xanthine oxidase system as a superoxide generator. One unit of SOD was defined as the enzyme amount causing $50 \%$ inhibition in the NBT reduction rate. SOD activity was given as units per milligram protein (U/mg protein).

\section{Determination of tissue glutathione (GSH) levels}

GSH content in tissue samples was measured spectrophotometrically according to Ellman's method ${ }^{15}$. In this method, thiols interact with 5 , 5'-dithiobis-(2-nitrobenzoic acid) (DTNB) and form a colored anion with maximum peak at 412 $\mathrm{nm}$. GSH levels were calculated from the standard calibration curve and expressed as $\mathrm{nmol} / \mu \mathrm{gr}$ protein.

\section{Histopathological studies of kidney and liver}

For histological and immunohistochemical studies, all animals were anesthetized by ketamin (40 mg/kg, Alfamine ${ }^{\circledR}$, Alfasan International B.V., Holland) and xylazine (4 $\mathrm{mg} / \mathrm{kg}$, Alfazyne ${ }^{\circledR}$, Alfasan International B.V., Holland) i.p. and perfused with $200 \mathrm{ml}$ of $4 \%$ formaldehyde in $0.1 \mathrm{M}$ phosphate-buffer saline (PBS). Formalin- fixed kidney and liver sections $(4 \mu \mathrm{m})$ were stained with hematoxylene \& eosine. All sections were photographed with Olympus C-5050 digital camera mounted on Olympus BX51 microscope.

Morphological evaluation was done by computerized image analysis system (Image- Pro Express 1.4.5, Media Cybernetics, Inc. USA) on 10 microscopic fields per section examined at a magnification of $\times 20$, by the observer blind to the study group.

Kidney sections from every rat in all groups were evaluated semi-quantitatively in terms of the extent of tubular epithelial necrosis, luminal necrotic debris, tubular dilatation, hemorrhage, and interstitial inflammation by being rated as follows: $0-5 \%=$ score $0 ; 6-20 \%=$ score $1 ; 21$ $40 \%=$ score $2 ; 41-60 \%=$ score $3 ; 61-80 \%=$ score 4 ; and $81-100 \%=$ score $5^{16,17}$.

\section{Statistical analysis}

Data are presented as mean values \pm standard error of the mean (SEM). Data analyses were performed using SPSS version 15.0 for Windows. All data were analyzed by non-parametric (MannWhitney $\mathrm{U}$ ) test. $p$ values of 0.05 or less were regarded as statistically significant.

\section{RESULTS}

\section{The evaluation of kidney tissues by biochemical tests}

Serum BUN and kidney tissue GSH levels for all 3 groups were provided in Table 1. The high level of BUN is an indicator of impaired kidney functions. BUN levels were significantly higher in CIS+ saline group than control group $(p<0,000)$. A significant decrease was also observed in CIS+CUR group compare to between CIS+ saline group $(p<0,01)$.

Table 1. The evaluation of serum BUN and kidney tissue GSH, MDA and SOD values

\begin{tabular}{|l|c|c|c|c|}
\hline Groups & $\begin{array}{c}\text { BUN }(\mathrm{mg} / \mathrm{dl})) \\
(\mathrm{mg} / \mathrm{dl})\end{array}$ & $\begin{array}{c}\text { GSH (Kidney) } \\
(\mathrm{nmol} / \mathrm{g} \text { tissue })\end{array}$ & $\begin{array}{c}\text { MDA (Kidney) } \\
(\mathrm{nmol} / \mathrm{g} \text { tissue })\end{array}$ & $\begin{array}{c}\text { SOD (Kidney) } \\
(\mathrm{U} / \mathrm{mg} \text { protein })\end{array}$ \\
\hline Control & $18.1 \pm 1.7$ & $11.7 \pm 1.3$ & $104.7 \pm 4.9$ & $0.09 \pm 0.009$ \\
\hline Cisplatin+saline & $77.2 \pm 8.1 * *$ & $8.06 \pm 0.94 \#$ & $173.7 \pm 10.2 * *$ & $0.03 \pm 0.006^{* *}$ \\
\hline Cisplatin+curcumin & $45.9 \pm 2.8^{*}$ & $13.6 \pm 1.01 \dagger$ & $138.1 \pm 6.9 *$ & $0.05 \pm 0.009 \#$ \\
\hline
\end{tabular}

$* * \mathrm{p}<0.000$ (different from control), ${ }^{*} \mathrm{p}<0.01$ (different from Cisplatin+saline)

$\# \mathrm{p}<0.001$ (different from control), $\uparrow \mathrm{p}<0.05$ (different from Cisplatin + saline) 
The kidney GSH that commonly used to exhibit damage due to oxidative stress was measured. It was found that there was a significant reduction in CIS+ saline group than control group $(p<0,001)$. In CIS+ CUR group, GSH value was higher than CIS+ saline group and it was statistically significant $(p<0,05)$.

Tissue MDA levels, indicator of lipid peroxidation, were measured and it was significantly higher in CIS group than control group [ $p<0,000]$. Additionally, it is observed to be decreased markedly in CIS+CUR group contrast to CIS+ saline group $(p<0,001)$ (Table 1).

Tissue SOD levels that decrease in oxidative stress were found lowest in CIS+ saline group group (Table 1). It was compared with control group and found significantly lower that control group $(p<0,000)$. A significant increase was also observed in CIS+CUR group compare to CIS+ saline group $(p<0.05)$.

\section{The evaluation of kidney tissues by histopathological findings}

The histopathological indicators of renal tubular damage as tubular epithelial necrosis, luminal necrotic debris and tubular dilatation were observed in CIS+ saline group. Tubular epithelial necrosis, luminal necrotic debris and tubular dilatation scores were markedly increased in CIS+ saline group $(p<0,000)$. In CIS+ CUR group, all kidney scores were significantly decreased contrast to CIS+ saline group. They were shown in Table 2.

Table 2. The evaluation of kidney histopathological scoring system for all groups

\begin{tabular}{|l|c|c|c|}
\hline Groups & $\begin{array}{l}\text { Tubular epithelial } \\
\text { necrosis }\end{array}$ & $\begin{array}{l}\text { Luminal necrotic } \\
\text { debris }\end{array}$ & Tubular Dilatation \\
\hline Control & 0 & 0 & 0 \\
\hline Cisplatin+saline & $2.6 \pm 0.3 * *$ & $3.1 \pm 0.2 \# \#+3 \dagger \dagger$ \\
\hline Cisplatin+curcumin & $1.7 \pm 0.28^{*}$ & $1.14 \pm 0.1 \#$ & $1.9 \pm 0.3 \dagger$ \\
\hline
\end{tabular}

$* * \mathrm{p}<0.000$ (different from control), * $\mathrm{p}<0.05$ (different from Cisplatin+saline) $\# \# \mathrm{p}<0.000$ (different from control), \# p<0.01 (different from Cisplatin+saline) $\uparrow \dagger \mathrm{p}<0.000$ (different from control), $\uparrow \mathrm{p}<0.001$ (different from Cisplatin + saline)

In figure 1, the images of histopathological alterations were presented for all groups. As shown, tubular epithelial necrosis and tubular dilatation were seen in CIS+ saline group and the amelioration was evident in CIS+ CUR group. 


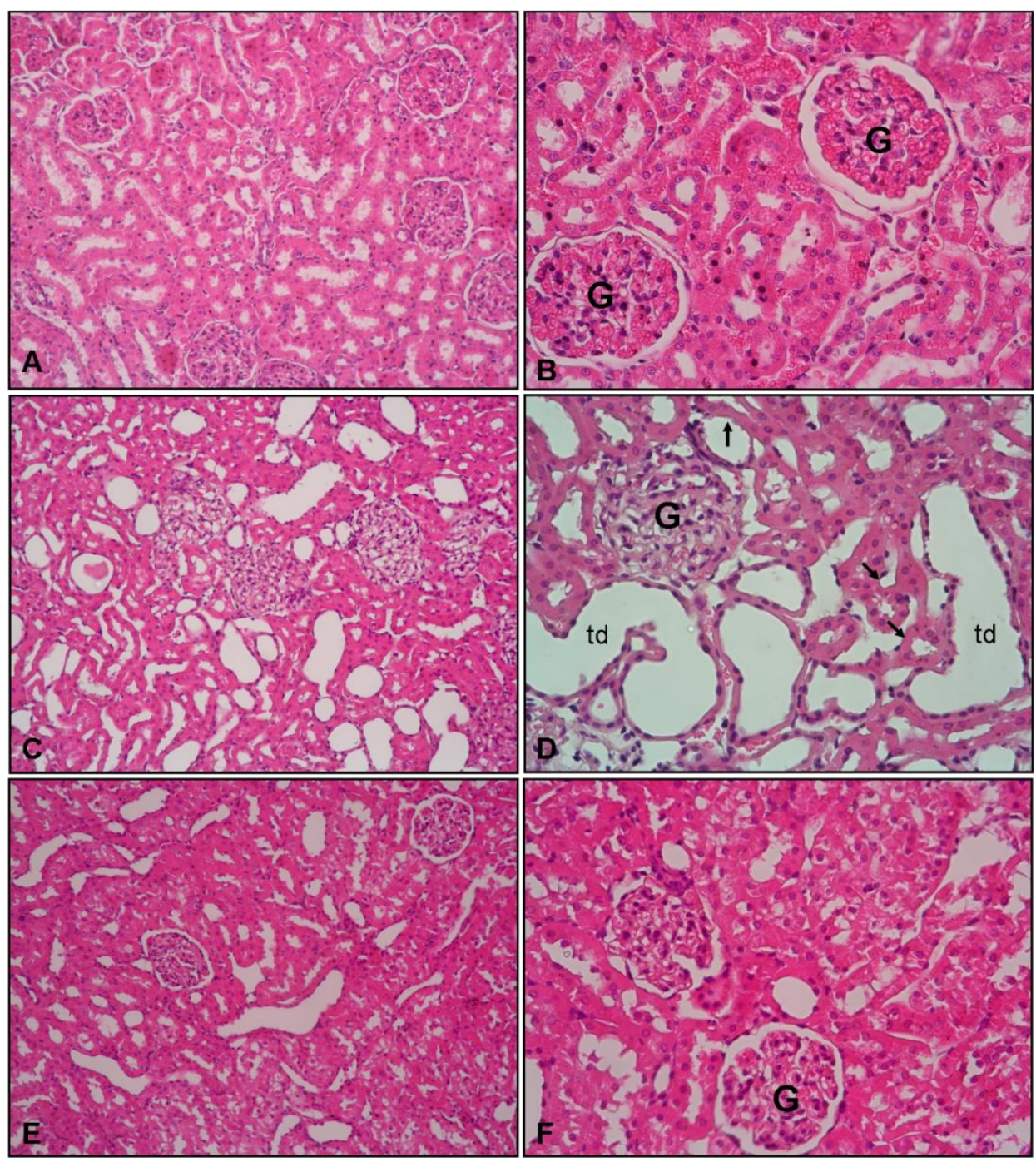

Figure 1: Kidney histolopathology H\& E (x 40 and x 100), A-B: Normal kidney (control group), C-D: tubular cell necrosis (arrow) and tubuler dilatation (td) (cisplatin and saline group), E-F: Decreased on tubuler dilatation and tubular cell necrosis (cisplatin and curcumin group)

\section{The evaluation of liver tissues by biochemical tests}

The liver function was assessed by measuring serum activities of ALT. The highest level of ALT was in CIS+ saline group. The mean values were 24.07, 83.7 and 50.5 in control group, CIS+ saline group and CIS+ CUR group respectively. There was a significant increase in CIS+ saline group compared with control group $(p<0,001)$. In CIS+ CUR group, there was markedly decrease compared with CIS+ saline group $(p<0,05)$ (Table $3)$.

Table 3. The evaluation of serum ALT and liver tissue GSH, MDA and SOD values

\begin{tabular}{|l|c|c|c|c|}
\hline Groups & $\begin{array}{c}\text { ALT (Liver) } \\
\text { (IU/L tissue) }\end{array}$ & $\begin{array}{c}\text { GSH (Liver) } \\
\text { (nmol/g tissue) }\end{array}$ & $\begin{array}{c}\text { MDA (Liver) } \\
\text { (nmol/g tissue) }\end{array}$ & $\begin{array}{c}\text { SOD (Liver) } \\
\text { (U/mg protein) }\end{array}$ \\
\hline Control & $24.07 \pm 4.6$ & $4.6 \pm 0.6$ & $26.8 \pm 3.6$ & $0.30 \pm 0.02$ \\
\hline Cisplatin+saline & $83.7 \pm 12.5^{* *}$ & $2.9 \pm 0.4 \#$ & $62.1 \pm 6.03 * * *$ & $0.12 \pm 0.01 \# \#$ \\
\hline Cisplatin+curcumin & $50.5 \pm 5.7^{*}$ & $5.05 \pm 0.3^{*}$ & $35.2 \pm 5.1^{\mathrm{\gamma}}$ & $0.23 \pm 0.03^{*}$ \\
\hline
\end{tabular}

$* * \mathrm{p}<0.001$ (different from control), $* \mathrm{p}<0.05$ (different from Cisplatin+saline)

$\# \mathrm{p}<0.01$ (different from control), \#\# $\mathrm{p}<0.000$ (different from control)

$* * * \mathrm{p}<0.0001$ (different from control), $\mathrm{y} \mathrm{p}<0.01$ (different from Cisplatin+saline) 
GSH values were measured in liver tissues (Table 3). Accordingly; it was found that there was a markedly reduction in CIS+ saline group compared with control group $(p<0,01)$. Liver GSH value in CIS+ CUR group was significantly higher than CIS+ saline group $(p<0,01)$.

Tissue MDA and SOD values were presented in table 3. It was found that MDA was higher in CIS+ saline group than control group $(p<0,001)$. Additionally, there was markedly decrease of MDA in CIS+CUR group compared with CIS+ saline group $(p<0,01)$. Tissue SOD values were found markedly high in CIS+ saline group compared with control group $(p<0,000)$ and in CIS+ CUR group, it was significantly lower than CIS+ saline group $(\mathrm{p}<0,01)$.

\section{The evaluation of liver tissues by histopathological findings}

As shown in figure 2, the histopathological signs of liver injury as central venous dilatation, hepatocytes necrosis and vacuolar changes of pericentral hepatocytes were seen in CIS+ saline group. In CIS+ CUR group, there was a reduction in signs of liver damage.

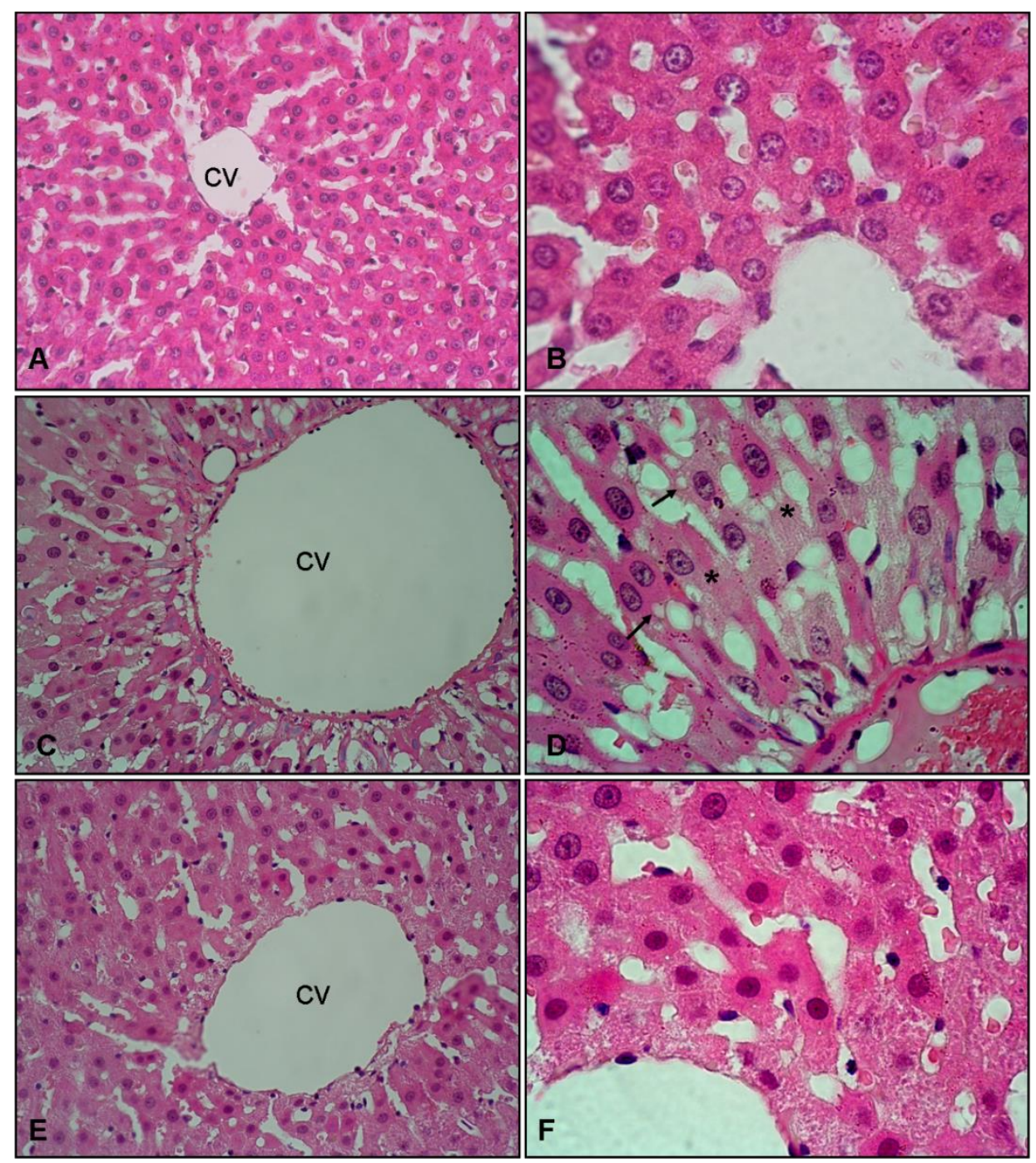

Figure 2: Liver histolopathology H\& E (x 40 and x 100), A-B: Normal liver (control group),

C-D: Vacuolar changes of pericentral hepatocytes (arrow), central venous (cv) dilatation (cisplatin and saline group) and hepatocyte necrosis (asteriks), E-F: Decreased central venous dilatation and hepatocyte necrosis (cisplatin and curcumin group)

\section{DISCUSSION}

In the present study, CIS induced kidney and liver injury were investigated by biochemical and histopathological findings. Particularly, the role of oxidative stress in both injuries and ameliorating role of CUR via antioxidant efficacy were tried to evaluate by MDA, GSH and SOD. In summary of our results, the beneficial effects of CUR were found on the nephrotoxicity and hepatotoxicity of CIS.

It is known that CIS causes nephrotoxicity and nephrotoxicity is a strong factor to restrict usage 
of CIS ${ }^{18}$. In the present study; the deterioration of kidney functions was shown by increased serum BUN level, histopathological images of kidney as tubular epithelial necrosis, luminal necrotic debris and tubular dilatation and also histopathological kidney score in CIS administrated group. In CUR treated group, BUN levels were lower than CIS group. It is an indicator that exhibits ameliorating effects of CUR on kidney functions. Similarly, the effects of CUR were studied on CIS induced nephrotoxicity by Kuhad et al. ${ }^{19}$. They reported that CUR leads to decrease in BUN levels with CIS administrated rats. Their results show that the level of decrease in BUN levels is associated with dosage of CUR. It is given high dose CUR in our study. Ueki et al. reported that BUN levels are lower in CUR treated CIS group than CIS group and in that study the dosage of CUR are same with current study ${ }^{20}$. Inversely, Antunes et al. suggest that CUR has no protection against CIS induced renal damage ${ }^{21}$. The statistically significant reduction in creatinine and increase in creatinine clearance are not shown in CIS+ CUR group compared with CIS group. They report that CUR does not offer treatment against CIS induced kidney injury. In that study, low dosages of CUR were given to rats in pretreatment stage, it may be a reason for this opposite results to our study. The histopathological indicators of renal damage were presented in this study and they were supported with biochemical results. Besides, the beneficial effects of CUR were shown by this way. Similar to present study, the histopathological images that shows changes of CIS induced kidney tissues are presented in previous studies ${ }^{16,20,22}$. Particularly, the impairment on tubules is remarkable.

The kidney scoring system also was used to present kidney injury and ameliorating effects of CUR. It is used same scoring system to display effects of CIS on kidney tissues with the report of Ashrafi et al. Similar to that study; the highest score was in CIS group ${ }^{16}$. In current study, the score of CUR treated group was lower than CIS group and it can be an indicator for benefit of CUR on kidneys besides other parameters. It shows the histopathological ameliorating effects of CUR on kidney tissues.

The pathogenesis of CIS induced nephrotoxicity is not completely clear but in recent studies it is shown to associate with cell membrane peroxidation, mitochondrial dysfunction, inhibition of protein synthesis, DNA damage, and inhibition of the antioxidant system by prooxidant damage to the renal tissue ${ }^{23}$. It is known that CIS gets accumulated on mitochondria of proximal tubules by reactive oxygen species
[ROS] and it directly destroys to structure of cell components, including lipids, proteins, and $\mathrm{DNA}^{6,23}$. The damage on mitochondria that increases free oxygen radicals and decreases antioxidant production as GSH and SOD plays an important role on the pathogenesis of CIS induces kidney injury ${ }^{2,6}$. Wasem et al. reported that a single dose of CIS caused serious damage on kidney, characterized by a significant increase in GSH levels ${ }^{24}$. They suggest that it is a sign of induction of oxidative stress and impairment on the cellular antioxidant mechanisms leading to active participation of GSH in cellular defence against ROS. GSH with high levels show the nonenzymatic antioxidant response to being subjected to oxidative stress of SOD and catalase ${ }^{24}$. GSH and SOD were used in the present study to indicate mechanism of CIS induced kidney and liver injuries and possible effects of CUR via oxidant- antioxidant pathways. Additionally, MDA is an end product of lipid peroxidation was used. It is known that ROS is a serious cause of lipid peroxidation ${ }^{25}$. The high levels of MDA in tissues are an indicator of increasing oxidative stress. Besides, the decrease in GSH and SOD can increase MDA ${ }^{26}$. In the current study, GSH and SOD values in kidney tissues were found lower and MDA values were found higher in CIS group than control group. It shows that CIS causes decrease in product of antioxidants and increase in lipid peroxidation. CUR is an herbal potent antioxidant. In literature, there are studies that report beneficial effects of CUR on CIS related kidney injury ${ }^{19,20,21}$. In the present study, there was decline in SOD and GSH levels and rise in MDA levels of kidney in CIS group with treated CUR. It is reported that CUR increases endogenous GSH and the activities of $\mathrm{SOD}^{27}$. It is suggested that CUR provides protection against CIS induced mitochondrial nephrotoxicity through antioxidants and oxidative stress biomarkers ${ }^{24}$. The results of the current study support the antioxidant activity of CUR.

The present study demonstrates CIS induced liver injury besides kidney injury. ALT was used to evaluate liver functions in all groups. The high levels of ALT were seen in CIS induced group and it was interpreted as liver injury. In recent studies, the hepatotoxicity of agents were also shown by high ALT levels ${ }^{28,29,30}$. The histopathological images were presented and central venous dilatation, vacuolar changes of pericentral hepatocyctes and necrosis of hepatocytes were evident in CIS group. In a study of Bentli et al., the hepatotoxic effects of CIS are studied and it is presented with high levels of AST 
and ALT besides histopathological findings as vacuolar changes of pericentral hepatocytes and central venous dilatation ${ }^{31}$. The mechanism that is responsible from hepatotoxicity of CIS still remains unclear. It is thought that as nephrotoxicity, oxidative stress play important role in pathogenesis of hepatotoxic effects of CIS on liver ${ }^{32}$. It is reported that oxidative stress due to the generation of ROS decreased antioxidant enzymes such as SOD and reduced non-enzymatic molecules as GSH and MDA which are the major variations in CIS induced hepatotoxicity ${ }^{33}$. Liver SOD and GSH levels were investigate lower in CIS group than control group and it may reflect increased ROS in liver and consequently, antioxidant mechanisms may be pressed. The high levels of liver MDA in CIS group may support this hypothesis. Sun et al. observed remarkable elevation in liver MDA levels and reduction in liver SOD and GSH levels in CIS treated rats ${ }^{33}$.

The evaluation of CUR was presented by lower ALT levels than CIS group and shown images that exhibit ameliorating effects of CUR histopathologically. The liver MDA, SOD and GSH were used to present beneficial effects and understand possible mechanism on liver injury. The healing effects of CUR on hepatic injury against different agents are reported in previous studies ${ }^{34,35}$. However, to our knowledge, there is a few data about CUR effects on CIS induced liver injury. Wasem et al. reported that pretreatment of high dose CUR has ameliorating effects on liver mitochondria against deleterious influence of CIS $^{36}$.

\section{CONCLUSION}

In the current study, the deleterious effects of CIS on kidney and liver via oxidative stress were presented. It is indicated that CUR has beneficial impact on CIS induced hepatotoxicity and nephrotoxicity. It is suggested that CUR may be an option for CIS treated patients to protect possible toxicity. The further studies that include human beings may be required about this issue.

\section{Acknowledgements}

There is no conflict of interest between authors of this study. The authors want to thank Dr. Turker Cavusoglu and Dr. Utku Ates for their contributions.

\section{REFERENCES}

1- Terada $Y$, Inoue $K$, Matsumoto $T$, Ishihara M, Hamada K, Shimamura Y. et al. 5Aminolevulinic Acid Protects against
Cisplatin-Induced Nephrotoxicity without Compromising the Anticancer Efficiency of Cisplatin in Rats In Vitro and In Vivo. PLoS One 2013, 6; 8: e80850.

2- Song J, Liu D1, Feng L, Zhang Z, Jia X, Xiao W. Protective Effect of Standardized Extract of Ginkgo biloba against Cisplatin-Induced Nephrotoxicity. Evid Based Complement Alternat Med 2013; 2013:846126.

3- Ajith TA, Usha S, Nivitha V. Ascorbic acid and alpha-tocopherol protect anticancer drug cisplatin induced nephrotoxicity in mice: a comparative study. Clin Chim Acta 2007; 375: 82-6.

4- Rubera I, Duranton C, Melis N, Cougnon M, Mograbi B, Tauc M. Role of CFTR in oxidative stress and suicidal death of renal cells during cisplatin-induced nephrotoxicity. Cell Death Dis 2013, 3; 4: e817.

5- Palipoch S, Punsawad C. Biochemical and histological study of rat liver and kidney injury induced by Cisplatin. J Toxicol Pathol 2013 ; 26: 293-9.

6- Ajith TA, Nivitha V, Usha S. Zingiber officinale Roscoe alone and in combination with alpha-tocopherol protect the kidney against cisplatin-induced acute renal failure. Food Chem Toxicol 2007; 45: 921-7.

7- Chirino YI, Pedraza-Chaverri J. Role of oxidative and nitrosative stress in cisplatininduced nephrotoxicity. Exp Toxicol Pathol 2009; 61: 223-42.

8- Yousef MI, Omar SA, El-Guendi MI, Abdelmegid LA. Potential protective effects of quercetin and curcumin on paracetamolinduced histological changes, oxidative stress, impaired liver and kidney functions and haematotoxicity in rat. Food Chem Toxicol 2010; 48: 3246-61.

9- Zhang H, Yu T, Wen L, Wang H, Fei D, Jin C. Curcumin enhances the effectiveness of cisplatin by suppressing CD133+ cancer stem cells in laryngeal carcinoma treatment. Exp Ther Med 2013; 6: 1317-21.

10- Mendonça LM, da Silva Machado C, Teixeira CC, de Freitas LA, Bianchi Mde L, Antunes LM. Curcumin reduces cisplatin-induced neurotoxicity in NGF-differentiated PC12 cells. Neurotoxicology 2013; 34: 205-11.

11- Gao S, Duan X, Wang X, Dong D, Liu D, Li $X$. et al. Curcumin attenuates arsenic-induced hepatic injuries and oxidative stress in 
experimental mice through activation of Nrf2 pathway, promotion of arsenic methylation and urinary excretion. Food Chem Toxicol 2013; 59: 739-47.

12- Trujillo J, Chirino YI, Molina-Jijón E, Andérica-Romero AC, Tapia E, PedrazaChaverrí J. Renoprotective effect of the antioxidant curcumin: Recent findings. Redox Biol 2013, 17; 1: 448-56.

13- Demougeot $C$, Marie $C$, Beley A: Importance of iron location in iron-induced hydroxyl radical production by brain slices. Life Sci 2000; 67: 399-41.

14- Sun Y, Oberley L, Li Y. A simple method for clinical assay of superoxide dismutase. Clin Chem 1988; 34:497-500.

15- Ellman GL: Tissue sulfhydryl groups. Arch Biochem Biophys 1959; 82: 70-77.

16- Ashrafi F, Nematbakhsh M, Safari T. A combination of vitamin $\mathrm{C}$ and losartan for cisplatin-induced nephrotoxicity in rats. Iran $\mathbf{J}$ Kidney Dis 2012; 6: 361-5.

17- Eren Z, Coban J, Ekinci ID. Evaluation of the effects of a high dose of erythropoietin-beta on early endotoxemia using a rat model. Adv Clin Exp Med 2012; 21: 321-9.

18- Beytur A, Köse E, Sarihan ME, Sapmaz HI, Dogan Z, Cetin A, et al. Beneficial effects of montelukast against cisplatin-induced acute renal damage in rats. Ren Fail 2012; 34: 343-9.

19- Kuhad A, Pilkhwal S, Sharma S, Tirkey N, Chopra K. Effect of curcumin on inflammation and oxidative stress in cisplatin-induced experimental nephrotoxicity. J Agric Food Chem 2007, 12; 55: 10150-5.

20- Ueki M, Ueno M, Morishita J, Maekawa N. Curcumin ameliorates cisplatin-induced nephrotoxicity by inhibiting renal inflammation in mice. J Biosci Bioeng 2013; 115: 547-51.

21- Antunes LM, Darin JD, Bianchi Nde L. Effects of the antioxidants curcumin or selenium on cisplatin-induced nephrotoxicity and lipid peroxidation in rats. Pharmacol Res 2001 ; 43: 145-50.

22- Nematbakhsh M, Pezeshki Z, Eshraghi-Jazi F, Ashrafi F, Nasri H, Talebi A, et al. Vitamin E, Vitamin C, or Losartan Is Not Nephroprotectant against Cisplatin-Induced Nephrotoxicity in Presence of Estrogen in
Ovariectomized Rat Model. Int J Nephrol 2012; 2012: 284896.

23- Silici S, Ekmekcioglu O, Kanbur M, Deniz K. The protective effect of royal jelly against cisplatin-induced renal oxidative stress in rats. World J Urol 2011; 29: 127-32.

24- Waseem M, Kaushik P, Parvez S. Mitochondria-mediated mitigatory role of curcumin in cisplatin-induced nephrotoxicity. Cell Biochem Funct 2013; 31: 678-84.

25- Sener MT, Sener E, Tok A, Polat B, Cinar I, Polat $\mathrm{H}$, et al. Biochemical and histologic study of lethal cisplatin nephrotoxicity prevention by mirtazapine. Pharmacol Rep 2012; 64: 594-602.

26- Maliakel DM, Kagiya TV, Nair CK. Prevention of cisplatin-induced nephrotoxicity by glucosides of ascorbic acid and alphatocopherol. Exp Toxicol Pathol 2008; 60: 5217.

27- Aldebasi YH, Aly SM, Rahmani AH. Therapeutic implications of curcumin in the prevention of diabetic retinopathy via modulation of anti-oxidant activity and genetic pathways. Int $\mathbf{J}$ Physiol Pathophysiol Pharmacol 2013, 15; 5: 194-202.

28- Gao S, Duan X, Wang X, Dong D, Liu D, Li $\mathrm{X}$, et al. Curcumin attenuates arsenic-induced hepatic injuries and oxidative stress in experimental mice through activation of $\mathrm{Nrf} 2$ pathway, promotion of arsenic methylation and urinary excretion. Food Chem Toxicol 2013; 59: 739-47.

29- Hemeida RA, Mohafez OM. Curcumin attenuates methotraxate-induced hepatic oxidative damage in rats. J Egypt Natl Canc Inst 2008; 20: 141-8.

30- Ingawale DK, Mandlik SK, Naik SR. Models of hepatotoxicity and the underlying cellular, biochemical and immunological mechanism[s]: A critical discussion. Environ Toxicol Pharmacol 2013, 21; 37: 118-33.

31- Bentli R, Parlakpinar H, Polat A, Samdanci E, Sarihan ME, Sagir M. Molsidomine prevents cisplatin-induced hepatotoxicity. Arch Med Res 2013; 44: 521-8.

32- Lu Y, Cederbaum AI. Cisplatin-induced hepatotoxicity is enhanced by elevated expression of cytochrome P450 2E1. Toxicol Sci 2006; 89: 515-23. 
33- Sun Y, Yang J, Wang LZ, Sun LR, Dong Q. Crocin attenuates cisplatin-induced liver injury in the mice. Hum Exp Toxicol 2014; 33: 85562 .

34- Li G, Chen JB, Wang $\mathrm{C}, \mathrm{Xu} \mathrm{Z}$, Nie H, Qin $\mathrm{XY}$, et al. Curcumin protects against acetaminophen-induced apoptosis in hepatic injury. World J Gastroenterol 2013, 14; 19: 7440-6.

35- Naik SR, Thakare VN, Patil SR. Protective effect of curcumin on experimentally induced inflammation, hepatotoxicity and cardiotoxicity in rats: evidence of its antioxidant property. Exp Toxicol Pathol 2011; 63: 419-31.

36- Waseem M, Parvez S. Mitochondrial dysfunction mediated cisplatin induced toxicity: modulatory role of curcumin. Food Chem Toxicol 2013; 53: 334-42. 